\title{
STABILITAS MIKROKAPSUL Lactobacillus acidophilus ATCC 314 TERHADAP PEMANASAN DAN PENYIMPANAN DALAM SELAI BUAH NANAS RENDAH GULA
}

\author{
[Stability of Microencapsulated Lactobacillus acidophilus ATCC 314 Against Heating and \\ Storage in Low Sugar Pineapple Jam]
}

\author{
Diana Lestari*, Tiffany Claudya, dan Rianita Pramitasari \\ Program Studi Teknologi Pangan, Fakultas Teknobiologi, Universitas Katolik Indonesia Atma Jaya, Jakarta
}

Diterima 31 Januari 2019 / Disetujui 6 Mei 2019

\begin{abstract}
Fruit jam added with probiotics is an innovation in food product development. In this research, pineapple jam was made not only to increase the economic value of the pineapple but also to add the health properties due to the addition of probiotics (Lactobacillus acidophilus). The objective of the study was to evaluate the stability of L. acidophilus microcapsules ATCC 314 against heating and storage in low sugar pineapple jam. L. acidophilus was microencapsulated with emulsification method using sodium alginate and oil with Tween 80 as the emulsifier. The microcapsules size was 40-60 $\mu \mathrm{m}$. Microencapsulation was found to improve the stability of L. acidophilus upon heat processing. Total healthy cells of the microencapsulated probiotics heated at 40 and $50^{\circ} \mathrm{C}\left(1.4 \times 10^{7} \mathrm{CFU} / \mathrm{mL} ; 6.9 \times 10^{6} \mathrm{CFU} / \mathrm{mL}\right)$ were higher than the free probiotic cells $\left(7.9 \times 10^{6} \mathrm{CFU} / \mathrm{mL} ; 4.5 \times 10^{6} \mathrm{CFU} / \mathrm{mL}\right)$. The stability of the encapsulated probiotics in pineapple jam at $4{ }^{\circ} \mathrm{C}(14$ days of storage) was also better than that of the free cells. Conclusively, microencapsulation process with alginate could increase probiotic stability, thus can be considered in probiotic pineapple jam development.
\end{abstract}

Keywords: emulsification technique, lactobacillus acidophilus, microencapsulation, pineapple jam, probiotic

\begin{abstract}
ABSTRAK
Selai dengan kandungan probiotik merupakan salah satu inovasi dalam pengembangan produk pangan. Dalam penelitian ini dilakukan pembuatan selai nanas yang tidak hanya meningkatkan nilai jual buah nanas tetapi juga memberikan nilai fungsional terhadap kesehatan pencernaan dikarenakan penambahan Lactobacillus acidophilus dengan metode mikroenkapsulasi. Penelitian ini bertujuan mengetahui stabilitas mikrokapsul L. acidophilus ATCC 314 terhadap pengaruh pemanasan dan waktu penyimpanan. Proses mikroenkapsulasi $L$. acidophilus dilakukan dengan teknik emulsifikasi menggunakan natrium alginat dan campuran minyak dengan emulsifier Tween 80. Ukuran mikrokapsul yang diperoleh sebesar 40-60 $\mu \mathrm{m}$. Metode mikroenkapsulasi terbukti dapat meningkatkan kestabilan $L$. acidophilus terhadap pengaruh pemanasan. Jumlah sel sehat termikroenkapsulasi pada suhu 40 dan $50^{\circ} \mathrm{C}$ lebih tinggi $\left(1,4 \times 10^{7} \mathrm{CFU} / \mathrm{mL}\right.$; $\left.6,9 \times 10^{6} \mathrm{CFU} / \mathrm{mL}\right)$ dibandingkan sel bebas $\left(7,9 \times 10^{6} \mathrm{CFU} / \mathrm{mL} ; 4,5 \times 10^{6} \mathrm{CFU} / \mathrm{mL}\right)$. Penyimpanan probiotik selama 14 hari dalam bentuk terenkapsulasi dalam selai nanas pada suhu $4^{\circ} \mathrm{C}$ lebih stabil dibandingkan sel bebas. Proses mikroenkapsulasi dapat menjaga stabilitas probiotik dan dapat diaplikasikan untuk mengembangkan produk selai nanas probiotik.
\end{abstract}

Kata kunci: Lactobacillus acidophilus, mikroenkapsulasi, probiotik, selai nanas, teknik emulsi

\section{PENDAHULUAN}

Pangan fungsional merupakan pangan yang memiliki fungsi tambahan terhadap kesehatan selain kandungan gizinya. Salah satu contoh pangan fung-

*Penulis Korespondensi:

Email: diana.lestari@atmajaya.ac.id sional yang berpotensi untuk dikembangkan adalah pangan fungsional berbasis probiotik. Probiotik merupakan mikroorganisme hidup yang apabila dikonsumsi dalam jumlah yang cukup dapat memberikan manfaat kesehatan (Kechagia et al., 2013). Menurut Kailasapathy (2002), jumlah probiotik yang sesuai untuk dikonsumsi per hari adalah sebanyak $10^{8}-10^{9}$ 
$\mathrm{CFU} / \mathrm{g}$ atau sebanyak $100 \mathrm{~g}$ produk yang mengandung $10^{6}-10^{7} \mathrm{CFU} / \mathrm{g}$.

Lactobacillus acidophilus adalah spesies probiotik yang termasuk dalam golongan bakteri asam laktat (BAL), yaitu bakteri yang menghasilkan asam laktat sebagai salah satu produk hasil fermentasi karbohidrat, seperti glukosa, galaktosa, laktosa, maltosa, dan sukrosa. Bakteri ini umumnya berbentuk batang dengan ukuran 2-10 $\mu \mathrm{m}$, tumbuh optimal pada suhu $37^{\circ} \mathrm{C}$ dan $\mathrm{pH} 5,5-6,0$, bersifat anaerob fakultatif, dan homofermentatif obligat. $L$. acidophilus sebagai probiotik dapat berperan dalam mengatasi beberapa penyakit pencernaan seperti diare, inflammatory bowel disease (IBD), serta lactose-intolerant. Bakteri ini juga dapat merangsang respon imun dan membantu mengendalikan kadar kolesterol darah (Jafarei dan Ebrahimi, 2011; Pandey et al., 2015). Lactobacillus acidophilus ATCC 314 diketahui merupakan probiotik dan dapat mereduksi kolesterol. Kemampuan ini disebabkan karena strain tersebut menghasilkan kolesterol reduktase yang mengonversi kolesterol menjadi koprostanol (Lye et al., 2010).

Sifat fungsional probiotik bergantung dari jumlah probiotik yang dapat bertahan di dalam produk, oleh karena itu dalam penelitian ini dilakukan pengujian stabilitas probiotik $L$. acidophilus selama pengolahan dan penyimpanan produk. Faktor-faktor yang dapat memengaruhi stabilitas probiotik kondisi lingkungan seperti suhu $\mathrm{pH}$, dan $\mathrm{a}_{\mathrm{w}}$ selama pemrosesan dan penyimpanan. Salah satu upaya untuk melindungi probiotik dari kondisi ekstrem lingkungan adalah enkapsulasi. Enkapsulasi didefinisikan sebagai sebagai kegiatan menyalut suatu material dengan material lain yang dapat dibuat salah satunya dalam skala mikro. Mikroenkapsulasi dapat melindungi materi inti dari lingkungan luar atau menciptakan suatu lingkungan tersendiri bagi materi inti (Burgain et al., 2011).

Selai buah merupakan bubur buah yang ditambahkan gula dan dimasak hingga mengental yang biasa dijadikan pendamping roti atau kue kering. Selai tergolong dalam intermediate moisture food (IMF), yaitu pangan semi basah yang memiliki nilai $a_{w}$ yang rendah $(0,7-0,85)$ sehingga memiliki umur simpan yang panjang. Hal ini disebabkan terbatasnya jumlah air yang dapat dimanfaatkan oleh mikroorganisme pembusuk. Sifat tersebut dapat disebabkan oleh selai pada umumnya memiliki kandungan gula yang tinggi yaitu $60-70 \%$ (Mutia dan Yunus, 2016), sehingga tidak dapat dikonsumsi oleh semua kalangan terutama penderita Diabetes Melitus.

Buah nanas dipilih karena nanas mengandung berbagai vitamin dan mineral terutama kalsium, potasium, serat dan vitamin $C$ yang cukup tinggi (Hossain et al., 2015), namun umumnya memiliki umur simpan yang pendek dan mudah busuk yang disebabkan oleh kandungan kadar air yang tinggi.
Sehingga dengan mengolah buah nanas menjadi selai, diharapkan dapat meningkatkan daya simpan dan nilai ekonomi buah nanas. Penelitian ini mengaplikasikan probiotik terenkapsulasi kedalam selai buah nanas yang telah dikurangi jumlah gula yang digunakan dan menambahkan chia seeds yang dapat menyerap air dan berperan sebagai gelling agent (Coorey et al., 2014), sehingga dapat menurunkan nilai $\mathrm{a}_{\mathrm{w}}$ produk dengan gula terbatas. Penelitian ini bertujuan menguji stabilitas probiotik $L$. acidophilus ATCC 314 terenkapsulasi terhadap suhu pengolahan dan waktu penyimpanan dalam produk selai nanas rendah gula.

\section{BAHAN DAN METODE}

\section{Bahan}

Bahan yang digunakan dalam penelitian ini adalah buah nanas madu Pemalang varietas Queen yang diperoleh dari pasar tradisional di daerah Gunung Sahari, Jakarta Pusat. Chia seeds, lemon dan gula pasir dari supermaket lokal. Kultur probiotik yang digunakan adalah L. acidophilus ATCC 314 di import oleh PT. Multi Rejeki dalam bentuk KWIKSTIK ${ }^{\mathrm{TM}}$.

\section{Preparasi kultur probiotik (Harmayani et al., 2001)}

Preparasi kultur L. Acidophilus mengacu pada Harmayani et al. (2001) dengan modifikasi waktu inkubasi menjadi 48 jam. Kultur L. acidophilus ditumbuhkan dalam media MRS Agar (MRSA) (M6411, HIMEDIA). Kemudian diambil 1 ose untuk ditumbuhkan dalam MRS Broth (MRSB) (GM369, HIMEDIA) selama 1 malam. Sebanyak $10 \mathrm{~mL}$ starter tersebut diinokulasikan ke dalam $1.000 \mathrm{~mL}$ MRSB, dengan kondisi inkubasi $37^{\circ} \mathrm{C}$ selama 48 jam. Biomassa yang didapat kemudian disentrifugasi dengan kecepatan $10.000 \mathrm{rpm}$ selama 10 menit pada suhu $4^{\circ} \mathrm{C}$, dan dicuci dengan $\mathrm{NaCl}$ steril $(0,85 \% \mathrm{~b} / \mathrm{v})$ sebanyak dua kali.

\section{Proses mikroenkapsulasi (Mandal dan Hati, 2017)}

Metode mikroenkapsulasi mengacu pada Mandal dan Hati (2017) dengan modifikasi fase pendispersi yang digunakan adalah minyak kelapa sawit. Metode mikroenkapsulasi yang digunakan adalah teknik emulsi yaitu emulsi water in oil (W/O) antara campuran materi inti dan dinding polimer alginat (fase terdispersi) dan minyak (fase pendispersi) dengan bantuan emulsifier. Setelah emulsi terbentuk, dilanjutkan dengan proses cross-linking dengan penambahan $\mathrm{CaCl}_{2}$ untuk membentuk gel sebagai dinding dari mikrokapsul.

Sebanyak $4 \mathrm{~g}$ natrium alginat teknis (PT. Brataco Chemical Indonesia) dilarutkan dalam $100 \mathrm{~mL}$ 
akuades dan disterilisasi. Larutan didinginkan hingga mencapai suhu $38-40^{\circ} \mathrm{C}$. Selanjutnya sebanyak $100 \mathrm{~mL}$ minyak kelapa sawit ditambah dengan $0,2 \%$ pengemulsi Tween 80 , dan disterilisasi $\left(121^{\circ} \mathrm{C}, 15\right.$ menit). $\mathrm{CaCl}_{2}$ (A-2114 AR, PT. Smart-Lab Indonesia) dilarutkan dalam akuades dengan konsentrasi 0,1 $\mathrm{M}$, kemudian disterilisasi dan didinginkan pada suhu $4^{\circ} \mathrm{C}$.

Setelah ketiga larutan disiapkan, sebanyak 20 $\mathrm{mL}$ larutan natrium alginat dicampurkan dengan 4 $\mathrm{mL}$ suspensi sel bakteri dan dihomogenisasi hingga tercampur rata. Campuran alginat dan sel kemudian diteteskan perlahan ke dalam minyak kelapa sawit, dengan agitasi $600 \mathrm{rpm}$. Setelah diagitasi selama 5 menit, sebanyak $100 \mathrm{~mL} \mathrm{CaCl}_{2} 0,1 \mathrm{M}$ steril ditambahkan ke dalam larutan minyak secara cepat untuk mengeraskan mikrokapsul yang terbentuk dan memecah emulsi. Mikrokapsul dipanen dengan cara disentrifugasi pada kecepatan $1.000 \mathrm{rpm}$ selama 10 menit pada suhu $4^{\circ} \mathrm{C}$. Selanjutnya mikrokapsul dicuci 2 kali dengan $0,1 \mathrm{M}$ larutan $\mathrm{CaCl}_{2}$ steril dan terakhir dicuci dengan akuades steril untuk memisahkan mikrokapsul dari minyak. Mikrokapsul disaring menggunakan kertas saring dan dipindahkan ke dalam cawan petri steril. Mikrokapsul disimpan dalam lemari pendingin pada suhu $4 \pm 1^{\circ} \mathrm{C}$. Mikrokapsul yang terbentuk diukur dengan menggunakan mikroskop yang dilengkapi dengan mikrometer okuler (perbesaran 10x).

\section{Perhitungan jumlah sel probiotik bebas dan sel terenkapsulasi (Grosso dan Fávaro-Trindade, 2004)}

Enumerasi sel probiotik bebas dilakukan dengan menumbukan suspensi probiotik pada media MRSA dengan metode agar sebar. Koloni sel yang tumbuh pada MRSA kemudian dihitung, sedangkan untuk sel terenkapsulasi, sebelum dilakukan perhitungan sel, mikrokapsul didisintegrasi terlebih dahulu menggunakan natrium sitrat 2\% (6132-04-3 PA, Merck Millipore) steril pada pH 7. Sebanyak $1 \mathrm{~g}$ sel dicampurkan dengan $9 \mathrm{~mL}$ natrium sitrat $2 \%(\mathrm{~b} / \mathrm{v})$ kemudian dihomogenisasi selama 5 menit. Setelah itu, campuran dibiarkan pada suhu $37^{\circ} \mathrm{C}$ sambil menunggu terjadinya pemisahan fase dan terjadinya proses rehidrasi sel, kurang lebih selama 10 menit. Selanjutnya suspensi tersebut ditumbuhkan pada media MRSA dengan metode agar sebar pada kondisi optimum untuk pertumbuhan.

Uji ketahanan sel terhadap suhu pemanasan (Grosso dan Fávaro-Trindade, 2004)

Sebanyak $1 \mathrm{~g}$ mikrokapsul atau $1 \mathrm{~mL}$ suspensi sel bebas dimasukkan ke dalam $10 \mathrm{~mL}$ akuades, kemudian dipanaskan pada suhu 40 dan $50^{\circ} \mathrm{C}$ selama 20 menit. Setelah dipanaskan, sel didinginkan pada suhu ruang dan kemudian langsung ditumbuhkan pada MRSA dengan metode agar sebar untuk sel bebas dan didisintegrasi terlebih dahulu dengan natrium sitrat $2 \%$ seperti pada perhitungan jumlah sel probiotik bebas dan terenkapsulasi.

\section{Enumerasi sel sehat setelah pemanasan (Purna- sari et al., 2015)}

Masing-masing kultur L. acidophilus bebas dan terenkapsulasi, hasil uji ketahanan suhu, diambil sebanyak $1 \mathrm{~mL}$, kemudian ditumbuhkan pada media MRSA yang disuplementasi dengan $\mathrm{NaCl} 1 \% \mathrm{~b} / \mathrm{v}$. Sel bakteri yang cedera tidak dapat tumbuh pada media MRSA yang disuplementasi dengan $\mathrm{NaCl} 1 \%$ $\mathrm{b} / \mathrm{v}$, sehingga hanya akan ditemukan sel sehat.

\section{Pembuatan selai buah nanas (Saputro et al., 2018)}

Pembuatan selai buah nanas mengacu pada Saputro et al. (2018) dengan modifikasi sari jeruk menjadi lemon, jumlah gula, dan penambahan chia seeds. Buah nanas yang digunakan dalam pembuatan selai ini adalah nanas segar yang dikupas dan diblender hingga didapatkan bubur buah yang konsisten. Sebanyak $100 \mathrm{~g}$ bubur buah dipanaskan hingga mendidih selama 20 menit kemudian ditambahkan $10 \mathrm{~g}$ gula dan $10 \mathrm{~mL}$ perasan air lemon dan diaduk hingga merata. Sebanyak $10 \mathrm{~g}$ mikrokapsul probiotik sebagai perlakuan atau $10 \mathrm{~mL}$ sel probiotik bebas sebagai kontrol ditambahkan ke dalam selai nanas yang berbeda, ketika suhu telah mencapai $40^{\circ} \mathrm{C}$, selanjutnya sebanyak $10 \mathrm{~g}$ chia seeds ditambahkan ke dalam selai dan diaduk hingga seluruh chia seeds dan probiotik tercampur merata. Chia seeds digunakan untuk mengikat air berlebih sehingga dihasilkan viskositas yang sesuai untuk selai (Coorey et al., 2014). Selai dimasukkan ke dalam botol selai kaca steril dan disimpan selama 2 minggu di dalam kulkas $\left(4^{\circ} \mathrm{C}\right)$ kemudian dianalisis viabilitasnya setiap 3 hari.

\section{Analisis stabilitas probiotik pada selai buah nanas selama penyimpanan (Grosso dan Fávaro- Trindade, 2004)}

Sebanyak $1 \mathrm{~g}$ selai nanas yang telah ditambahkan probiotik bebas dilarutkan dalam $9 \mathrm{~mL} \mathrm{NaCl}$ 0,85\% kemudian ditumbuhkan pada media MRSA. Selai yang mengandung mikrokapsul diawali dengan dilakukan disintegrasi dengan $2 \%$ natrium sitrat terlebih dahulu sebelum dilakukan pengenceran dan ditumbuhkan pada media MRSA seperti pada perhitungan jumlah sel probiotik bebas dan terenkapsulasi.

\section{Analisis statistik}

Data pertumbuhan probiotik dengan dua ulangan dianalisis menggunakan ANOVA dengan uji lanjut Duncan. Analisis data dilakukan dengan menggunakan software IBM statistical package for the social 
science (SPSS) pada tingkat signifikansi $P<0,05$ atau tingkat kepercayaan $95 \%$.

\section{HASIL DAN PEMBAHASAN}

\section{Jumlah sel probiotik bebas dan terenkapsulasi}

Mikrokapsul probiotik $L$. acidophilus yang terbentuk dari hasil mikroenkapsulasi dengan metode emulsifikasi berbentuk bulat, tidak beraturan, berwarna putih dan ukurannya bervariasi dengan kisaran 40-60 $\mu \mathrm{m}$ (Gambar 1). Bentuk tampilan fisik mikrokapsul yang dihasilkan sudah sesuai dengan literatur, yaitu bahwa mikrokapsul umumnya memiliki ukuran yang bervariasi dengan kisaran 0,2-5.000 $\mu \mathrm{m}$. Bentuk mikrokapsul yang dihasilkan dengan metode emulsifikasi tidak seragam, namun bentuk umumnya bulat (Silva et al., 2014). Mikrokapsul Lactobacilus plantarum dengan teknik emulsi menghasilkan ukuran dengan kisaran 100-500 $\mu \mathrm{m}$ (Purnasari et al., 2015).

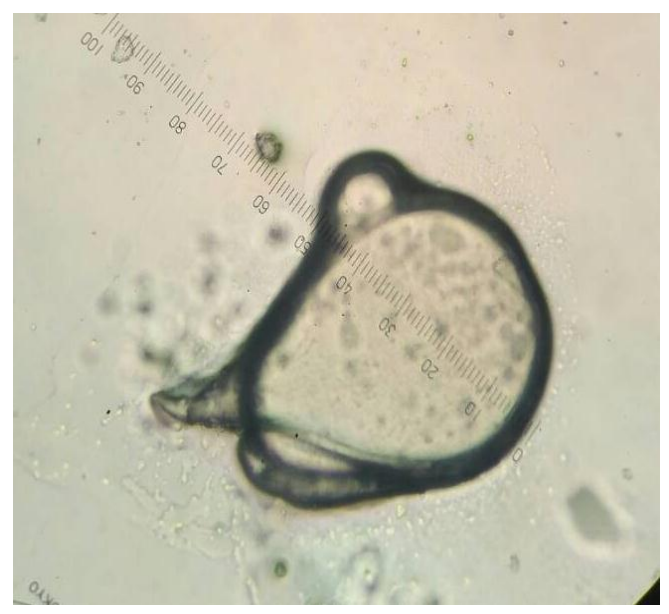

Keterangan: Perbesaran menggunakan mikroskop okuler dengan perbesaran $10 x$

\section{Gambar 1. Bentuk mikrokapsul}

Hasil enumerasi jumlah sel bebas awal yang tumbuh adalah $3,0 \times 10^{7} \mathrm{CFU} / \mathrm{mL}$. Sel bebas yang telah ditumbuhkan kemudian dimikroenkapsulasi dan hasil enumerasi sel probiotik yang terenkapsulasi adalah $3,6 \times 10^{7} \mathrm{CFU} / \mathrm{mL}$. Kedua nilai ini tidak berbeda signifikan secara statistik yang berarti proses mikroenkapsulasi berjalan dengan baik dan tidak memengaruhi jumlah sel bakteri yang dienkapsulasi. Berdasarkan hasil tersebut, total sel masing-masing perlakuan masih memenuhi kriteria jumlah probiotik minimal yang ditambahkan dalam produk pangan untuk dapat memberikan manfaat yang efektif terhadap kesehatan manusia, yaitu $10^{6}-10^{7} \quad \mathrm{CFU} / \mathrm{g}$ (Kailasapathy, 2002).

\section{Jumlah sel probiotik bebas dan mikrokapsul se- telah pemanasan}

Hasil uji sel probiotik bebas dan mikrokapsul terhadap panas pada dua suhu yang berbeda (40 dan $50^{\circ} \mathrm{C}$ ) disajikan dalam Tabel 1. Berdasarkan Tabel 1 dapat dilihat bahwa L. acidophilus dalam bentuk mikrokapsul memiliki ketahanan panas yang lebih baik dibandingkan sebelum dimikroenkapsulasi (sel bebas). Pada perlakuan sel bebas paparan panas 40 dan $50^{\circ} \mathrm{C}$ menurunkan L. acidophilus secara signifikan dengan jumlah sebelum dipanaskan. Perlakukan mikrokapsul pada suhu $40^{\circ} \mathrm{C}$ tidak menurunkan jumlah $L$. acidophilus secara signifikan dibanding sebelum pemanasan, sedangkan pada suhu $50^{\circ} \mathrm{C}$ menunjukkan penurunan yang signifikan. Meskipun demikian, jumlah sel $L$. acidophilus dalam mikrokapsul setelah pemanasan $50^{\circ} \mathrm{C}$ masih memberikan angka $10^{7}$, yang berarti masih lebih tinggi dibandingkan perlakuan sel bebas 40 dan $50^{\circ} \mathrm{C}$. Dengan demikian, dapat dikatakan bahwa proses mikroenkapsulasi dapat berperan menjaga kestabilan sel probiotik dari pengaruh suhu pemanasan (Mansouripour et al., 2013). Mikroenkapsulasi dengan teknik emulsi dapat meningkatkan sintasan probiotik terhadap suhu pemanasan, $\mathrm{pH} 2$ dan garam empedu $(0,5 \%)$ (Jati et al., 2015).

Tabel 1. Rata-rata jumlah sel probiotik sebelum dan setelah pemanasan $(\mathrm{CFU} / \mathrm{mL})$

\begin{tabular}{lccc}
\hline \multicolumn{1}{c}{ Perlakuan } & $\begin{array}{c}\text { Tanpa } \\
\text { Pemanasan }\end{array}$ & $40^{\circ} \mathrm{C}$ & $50^{\circ} \mathrm{C}$ \\
\hline Sel bebas & $3,0 \times 10^{/ \mathrm{a}}$ & $9,8 \times 10^{6 \mathrm{~b}}$ & $6,7 \times 10^{6 \mathrm{~b}}$ \\
Mikrokapsul & $3,6 \times 10^{\mathrm{a}}$ & $3,1 \times 10^{/ \mathrm{a}}$ & $1,0 \times 10^{/ \mathrm{b}}$ \\
\hline
\end{tabular}

Keterangan: Rataan dengan huruf yang berbeda (a-b) menunjukan menunjukan hasil beda nyata $(P<0,05)$

\section{Jumlah sel probiotik bebas dan mikrokapsul se- hat}

Proses pemanasan menyebabkan L. Acidophilus yang tumbuh dapat terbagi menjadi dua yaitu sel cidera dan sel sehat. Diharapkan jumlah sel sehat yang bertahan setelah pemanasan masih cukup banyak dan memenuhi nilai minimum probiotik dalam produk pangan.

Berdasarkan Tabel 2, dapat diketahui bahwa jumlah sel sehat tertinggi ditemui pada perlakuan mikrokapsul dengan pemanasan $40^{\circ} \mathrm{C}$, dilanjutkan mikrokapsul $50^{\circ} \mathrm{C}$, sel bebas $40^{\circ} \mathrm{C}$ dan sel bebas $50^{\circ} \mathrm{C}$ dengan perbedaan yang signifikan. Hal ini sesuai dengan teori dengan semakin meningkatnya suhu maka jumlah sel yang sehat akan menurun Enkapsulasi menggunakan alginat dapat mempertahankan jumlah sel probiotik sehat dibandingkan yang tidak dienkapsulasi (Mansouripour et al., 2013). Hasil yang sama juga ditemukan pada Purnasari et al. (2015) bahwa probiotik yang dienkapsulasi dengan alginat menunjukan jumlah sel se- 
hat yang lebih tinggi dibandingkan sel bebas tanpa perlakuan enkapsulasi.

Tabel 2. Jumlah sel probiotik sehat setelah pemanasan $(\mathrm{CFU} / \mathrm{mL})$

\begin{tabular}{|c|c|c|}
\hline Perlakuan & $40^{\circ} \mathrm{C}$ & $50^{\circ} \mathrm{C}$ \\
\hline Sel bebas & $7,9 \times 10^{6 a}$ & $4,5 \times 10^{66}$ \\
\hline Mikrokapsul & $1,4 \times 10^{/ c}$ & $6,9 \times 10^{6 a b}$ \\
\hline
\end{tabular}

\section{Stabilitas probiotik pada selai nanas selama pe- nyimpanan}

Kandungan probiotik sel bebas mengalami penurunan jumlah sel yang cukup besar selama penyimpanan 14 hari pada suhu $4^{\circ} \mathrm{C}$ yaitu sebesar 2,6 $\log \mathrm{CFU} / g$ selai. Sedangkan, pada selai nanas dengan mikrokapsul probiotik, jumlah sel mikrokapsul yang turun lebih kecil yaitu hanya $0,8 \log \mathrm{CFU} / \mathrm{g}$ (Gambar 2). Hal ini berarti mikrokapsul mempertahankan jumlah sel probiotik selama penyimpanan. Dengan melakukan metode mikroenkapsulasi, stabilitas probiotik di dalam selai buah nanas dapat ditingkatkan. Meskipun begitu, penurunan sel masih terjadi, hal tersebut disebabkan karena asam laktat yang dihasilkan dapat berperan sebagai agen pengelat terhadap ikatan kalsium-alginat yang terbentuk pada mikrokapsul, sehingga dapat menyebabkan kebocoran materi inti (Kailasapathy, 2002). Penelitian serupa yaitu enkapsulasi probiotik dalam selai salak menunjukan penurunan sebesar 3 log CFU/g selai setelah disimpan selama 4 minggu (Purnasari et al., 2015). Pada penelitian tersebut selai dapat diamati hingga 4 minggu karena kandungan gula yang sangat tinggi (75\%), sedangkan pada penelitian ini hanya menggunakan $10 \%$ gula dari total bobot bubur buah yang digunakan.

Gambar 2 juga melaporkan bahwa terdapat kontaminasi pertumbuhan khamir pada selai nanas yang dibuat yaitu mulai hari ke-10 pada selai nanas yang mengandung probiotik bebas dan hari ke-14 pada selai nanas yang mengandung mikrokapsul. Khamir merupakaan organisme yang tersebar luas di alam dan banyak ditemukan pada makanan, diantaranya buah-buahan. Khamir membutuhkan nutrisi berupa karbon, nitrogen, vitamin, dan mineral yang serupa dengan nutrisi yang terdapat pada makanan untuk dapat bertahan hidup. Selain itu, khamir dapat bertahan pada kondisi anaerob serta $\mathrm{pH}$ dan kadar air rendah, sehingga memungkinkan untuk tumbuh pada selai buah nanas (Stratford, 2006). Sebagian besar khamir tetap dapat tumbuh dengan baik pada suhu rendah, penyimpanan pada suhu kulkas hanya dapat memperlambat pertumbuhan khamir tetapi tidak dapat mencegah (Fleet, 2011).

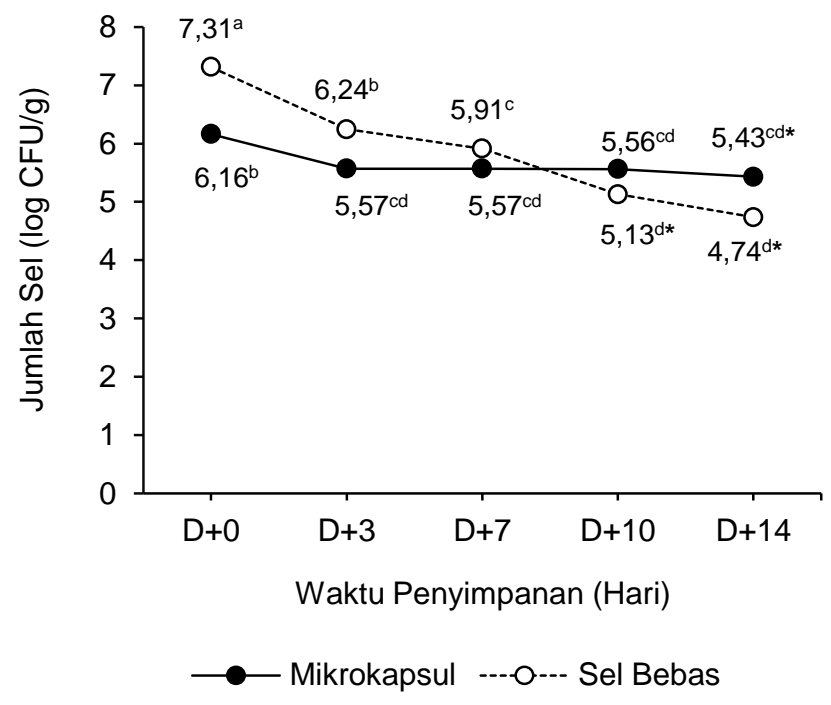

Keterangan: Rataan dengan huruf yang berbeda (a-d) menunjukkan hasil beda nyata $(P<0,05) .\left(^{*}\right)$ menandakan adanya pertumbuhan khamir

Gambar 2. Jumlah L. acidophilus perlakuan sel bebas dan mikrokapsul dalam selai buah nanas selama penyimpanan 2 minggu

Penyimpanan probiotik dalam bentuk terenkapsulasi terlihat lebih stabil dari hari ke harinya dibandingkan sel bebas saja. Sehingga aplikasi mikrokapsul dalam produk selai sangat menjanjikan. Sayangnya formulasi selai dengan kandungan gula yang rendah (menambahkan chia seed sebagai pengikat air) yang diharapkan dapat memberikan efek kesehatan dalam penelitian ini menyebabkan khamir menjadi mudah tumbuh dan mengontaminasi produk. Perlu juga dilakukan optimasi formula selai untuk memperoleh umur simpan yang lebih panjang sehingga dapat mengakomodasi jumlah selai probiotik yang masih dalam jumlah yang baik. Efek penyimpanan dalam selai nanas menunjukkan probiotik dengan enkapsulasi menggunakan alginat menghasilkan angka pertumbuhan yang jauh lebih stabil dibandingkan tanpa enkapsulasi (sel bebas).

\section{KESIMPULAN}

Bakteri probiotik L. acidophilus ATCC 314 yang di mikroenkapsulasi menghasilkan mikrokapsul dengan ukuran 40-60 $\mu \mathrm{m}$. Metode mikroenkapsulasi terbukti dapat meningkatkan kestabilan mikrokapsul L. acidophilus terhadap kenaikan suhu hingga $50^{\circ} \mathrm{C}$ dengan jumlah sel sehat $\left(6,9 \times 10^{6} \mathrm{CFU} / \mathrm{mL}\right)$ lebih tinggi dibandingkan sel bebas $\left(4,5 \times 10^{6} \mathrm{CFU} / \mathrm{mL}\right)$. Penyimpanan selai selama 14 hari menunjukan jumlah penurunan sel yang jauh lebih kecil pada perlakuan enkapsulasi yaitu hanya 0,8 log CFU/g selai di- 
bandingkan sel bebas yaitu sebesar 2,6 log CFU/g selai. Penyimpanan probiotik dalam bentuk terenkapsulasi dalam selai nanas lebih stabil dibandingkan sel bebas hingga hari ke-14.

\section{UCAPAN TERIMA KASIH}

Ucapan terima kasih penulis tujukan kepada Lembaga Penelitian dan Pengabdian Masyarakat Universitas Katolik Indonesia Atma Jaya yang telah mendanai penelitian ini melalui Hibah Penelitian Fakultas.

\section{DAFTAR PUSTAKA}

Burgain J, Gaiani C, Linder M, Scher J. 2011. Encapsulation of probiotic living cells: From laboratory scale to industrial applications. J Food Eng 104: 467-483. DOI: 10.1016/j.jfoodeng.20 10.12.031.

Coorey R, Tjoe A, Jayasena V. 2014. Gelling properties of chia seed and flour. J Food Sci 79: 859-866. DOI: 10.1111/1750-3841.12444.

Fleet GH. 2010. Yeast Spoilage of Foods and Beverages. Di dalam: Kurtzman CP, Fell JW, Boekhout T. The Yeasts (Fifth Edition). 53-63. Elsevier B.V. DOI: 10.1016/B978-0-444-521491.00005-7.

Grosso CRF, Fávaro-Trindade CS. 2004. Stability of free and immobilized Lactobacillus acidophilus and Bifidobacterium lactis in acidified milk and of immobilized $B$. lactis in yoghurt. Braz $\mathrm{J}$ Microbiol 35: 151-156. DOI: 10.1590/S1517-83 822004000100025.

Harmayani E, Ngatirah, Rahayu ES, Utami T. 2001. Ketahanan dan viabilitas probiotik bakteri asam laktat selama proses pembuatan kultur kering dengan metode freeze dan spray drying. J Teknol Industri Pangan 12: 126-132.

Hossain MF, Akhtar S, Anwar M. 2015. Nutrional value and medicinal benefits of pineapple. Int $\mathrm{J}$ Nutr Food Sci 4: 84-88. DOI: 10.11648/j.ijnfs.20 150401.22.

Jafarei P, Ebrahimi MT. 2011. Lactobacillus acidophillus cell structure and application. Afr $\mathrm{J}$ Microbiol Res 5: 4033-4042. DOI: 10.5897/AJM R11.630.

Jati AUP, Jenie BSL, Suliantari. 2015. Mikroenkapsulasi Lactobacillus sp. dengan teknik emulsi dan aplikasinya pada dodol sirsak. J Teknol
Industri Pangan 26: 135-143. DOI: 10.6066/jtip. 2015.26.2.135.

Kailasapathy K. 2002. Microencapsulation of probiotic bacteria: Technology and potential applications. Curr Issues Intest Microbiol 3: 39-48.

Kechagia M, Basoulis D, Konstantopoulou S, Dimitriadi D, Gyftopoulou K, Skarmoutsou N, Fakiri EM. 2013. Health Benefits of Probiotics: A Review. ISRN Nutr 2013: 1-7. DOI: 10.5402/2013/ 481651.

Lye HS, Rusul G, Liong MT. 2010. Removal of cholesterol by lactobacilli via incorporation and conversion to coprostanol. J Dairy Sci 93: 13831392. DOI: $10.3168 /$ jds.2009-2574.

Mandal S, Hati S. 2017. Microencapsulation of Bacterial Cells by Emulsion Technique For Probiotic Application. Didalam Emmanuel C, Opara, (Ed). Cell Microencapsulation: Methods and Protocols, Methods in Molecular Biology. 273279. Springer Science Business Media, New York. DOI: 10.1007/978-1-4939-6364-5_22.

Mansouripour S, Esfandiari Z, Nateghi L. 2013. The effect of heat process on the survival and increased viability of probiotic by microencapsulation - a review. Ann Biol Res 4: 83-87.

Mutia AK, Yunus R. 2016. Pengaruh penambahan sukrosa pada pembuatan selai langsat. Jtech 4: 80-84.

Pandey KR, Naik SR, Vakil BV. 2015. Probiotics, prebiotics, and synbiotics - a review. J Food Sci Technol 52: 7577-7587. DOI: 10.1007/s13197015-1921-1.

Purnasari N, Jenie BSL, Nuraida L. 2015. Karakteristik mikrokapsul Lactobacillus plantarum dan stabilitasnya dalam produk selai salak. J Teknol Industri Pangan 26: 90-99. DOI: 10.6066/jtip. 2015.26.1.90.

Rawat S. 2015. Food Spoilage: Microorganisms and their prevention. Asian J Plant Sci Res 5: 47-56.

Saputro TA, Permana IDGM, Yusasrini NLA. 2018. Pengaruh perbandingan nanas (Ananas comosus L. Merr.) dan sawi hijau (Brassica juncea L.) terhadap karakteristik selai. J IImu Teknol Pangan (ITEPA) 7: 52-60.

Silva PT, Fries LLM, Menezes CR, Holkem AT, Schwan CL, Wigmann EF, Bastos JO, Silva CB. 2014. Microencapsulation: concepts, mechanisms, methods and some applications in food technology. Cienc Rural 44: 1304-1311. DOI: 10.1590/0103-8478cr20130971. 